\title{
Nursing Students' Perceptions and Acceptance of Online Learning during the COVID-19 Pandemic in Indonesia
}

\author{
Cipta Pramana ${ }^{1,2,3 *} \mathbb{D}$, Oktia Woro Kasmini Handayani ${ }^{4}$, Tri Joko Raharjo ${ }^{3}$, Sri Ratna Rahayu ${ }^{5}$ \\ ${ }^{1}$ Department of Obstetrics and Gynecology, Medical Faculty, Tarumanagara University, Jakarta, Indonesia; ${ }^{2}$ Department of \\ Obstetrics and Gynecology, K.R.M.T. Wongsonegoro Hospital, Semarang, Indonesia; ${ }^{3}$ Postgraduate Program in Education \\ Management, Universitas Negeri Semarang, Indonesia Postgraduate Program in Education Management, Semarang State \\ University, Indonesia; ${ }^{4}$ Department of Public Health, Universitas Negeri Semarang, Indonesia; ${ }^{5}$ Master's of Public Health, \\ Postgraduate, Universitas Negeri Semarang, Indonesia
}

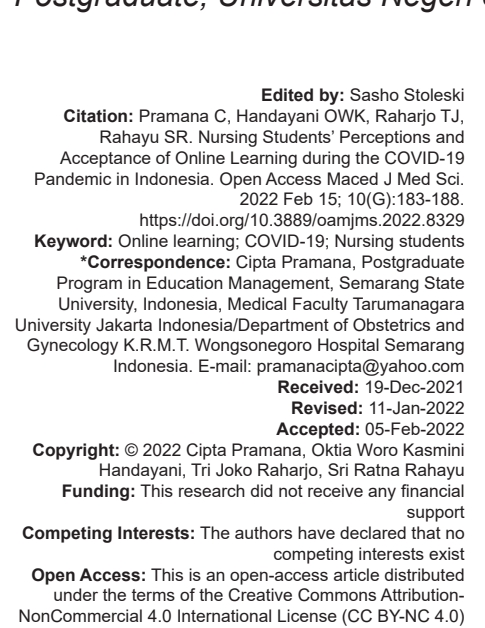

\section{Introduction}

The global pandemic caused by SARSCoV-2 has caused unprecedented large and wide changes in almost every aspect of the lives of the world's people. Moreover, throughout the United States, social distancing regulations began in March 2020. Education for medical students underwent significant changes in the learning process. For most medical students across the country, all clinical learning has been suspended indefinitely according to the recommendations of the Association of American Medical Colleges on March 17, 2020 [1]. The WHO declared SARS-CoV-2 infection a pandemic on March 11, 2020 [2].

In Indonesia, the first case of COVID-19 was on March 2, 2020; and in the city of Semarang, the first case was reported on March 17, 2020 [3] Moreover, various ways are done to reduce the transmission of the virus, among others, using standard face masks, maintaining physical distance, maintaining social distance, and finally vaccination against COVID-19 so that herd immunity can occur [4], [5].

The impact of the pandemic has also affected the world of education in Indonesia. To prevent the transmission of COVID-19, the Minister of Education and Culture Nadiem Anwar Makarim issued Circular Letter Number 4 of 2020 concerning the Implementation of Education in the Coronavirus Disease (COVID-19) Emergency Period. One important point is related to learning from home. The learning activities and tasks may vary between students, according to their respective interests and conditions, including in terms of access gaps/learning facilities at home [6].

Lectures and learning on campus which were originally conducted face-to-face have turned into a form of distance learning or online learning. Online learning is nothing new in the world of education. Online learning requires knowledge about the use of information technology by lecturers and students. There are advantages and disadvantages, but the online learning process will increase student motivation to learn and take responsibility independently [7], [8], [9]. 
Some of the advantages of distance learning are time and cost-effectiveness. Students and lecturers can manage their time very flexibly. With advances in technology, information, and communication, many learning platforms can be done online. A study on online learning was conducted involving 40 universities in Indonesia during the COVID-19 pandemic. There are 16 media used for distance learning, namely: WhatsApp, Zoom meeting, Google Meet, Edmodo, Google Classroom, Video Call, Email, E-Learning, Webex, Facebook, Schoology, padlet, Microsoft Team, Moodle, Blog, and YouTube. The most frequently used platform is WhatsApp (25\%), followed by Zoom meeting $(22 \%)$ and Google Classroom (15\%). WhatsApp is a platform that is often used because it is the easiest to access and operate. The most common problem encountered during distance learning is unstable signals, especially in mountainous areas [10]. In another study, it was shown that the online learning platforms that are often used are Zoom, Microsoft Teams, and WhatsApp [11].

With the change in the distance learning system in several campuses in Indonesia, those who are not used to doing it face many obstacles. The obstacles found were that it was difficult for students to understand the material given by the lecturer because of the lack of interaction between lecturers and students, lack of concentration in the lecture process, and both of these things led to a lack of effectiveness in the learning process [12], [13]. In addition to technical and internet issues, data privacy and security are factors that make the online learning process less effective. However, there are several advantages obtained that students are motivated to learn independently, low costs, convenience, and flexibility [11], [14], [15], [16], [17], [18], [19], [20], [21], [22].

With the COVID-19 pandemic, educational institutions around the world are closed because it will endanger students, including their teachers. So that most educational institutions have started to switch from classroom learning platforms to online learning. Especially for nursing students, online learning [13], $[14,[23]$ materials are poorly understood because in nursing science, there is practical learning to patients that cannot only be carried out online learning, but are each educational institution and students ready with a new model of a learning platform? [24], [25], [26] In this study, we focused on knowing the perceptions and acceptance of nursing students toward online learning through a survey of 404 students.

The research that we conducted was to find out about the perceptions of nursing students about the online learning process during the COVID-19 pandemic in Indonesia, including (1) Characteristics of the respondents, (2) platforms that are often used, (3) advantages and disadvantages/disadvantages of the online learning process, (4) respondents' perceptions of online learning and (5) factors that influence the perception and acceptance of online learning.

\section{Methods}

\section{Participants}

The research is in the form of a survey using Google forms about perceptions and acceptance of online lectures during the COVID-19 pandemic for nursing students at various universities in Indonesia. The questionnaire was sent through WhatsApp and randomly collected 404 nursing students from various universities in Indonesia. Participants voluntarily took the survey and participants agreed before answering online. To minimize bias in surveys, Google forms are limited to one response per account and allow people to complete the form only once, in addition, there is no pressure to influence answers and there are no rewards or fees to participants.

\section{Data collection procedures}

The research was conducted in July 2021 when the learning process was still online. An online survey using Google forms distributed through WhatsApp to nursing students consists of (1) characteristics of students, namely, age, education level, semester has taken, skills in using technology, information, and communication facilities, (2) the learning platform used, (3) the advantages and disadvantages of online learning, and (4) students' perceptions of online learning were assessed using a reliable instrument with a Crobanch alpha value of 0.93 . Participation in the study is voluntary, personal data and information are not collected. This study was approved by the Research Ethics Committee of the K.R.M.T Wongsonegoro Regional Hospital, Semarang City.

\section{Data analysis}

The data analysis process goes through several stages, namely: (1) Editing is done using the help of MS Excel software (version 2016. Redmond, USA) by selecting respondents according to the sample criteria, ensuring all respondents fill out the form completely, filtering missing data; (2) coding is done by changing qualitative data into quantitative data in the categorical form; (3) tabulation and data entry are done by summarizing the data into variables needed in the analysis and then the data are imported into SPSS software (version 23. Inc. Chicago, IL USA); and (4) data analysis consists of two, namely, univariate and bivariate analysis. Univariate analysis was conducted to obtain a description of the characteristics of the respondents along with the distribution of research variables by displaying the proportion of data (mean, standard deviation (SD), frequency, and percentage). Bivariate analysis was conducted to examine the factors that influence student perceptions using the Chi-square test with a significance value of 0.05 . 


\section{Results}

Table 1 shows the characteristics of respondents including age, education level, semester taken, skills in using Information and Communication Technology (ICT) and experience in participating in online learning before the pandemic. The majority of respondents are in the age range of 17-19 years $(50 \%)$ with a Diploma student's level $(62.9 \%)$. The most of the respondents took the third semester (33.2\%), dominantly having moderate/intermediate ICT skills $(82.2 \%)$ and had never participated in online learning before the pandemic (75.5\%).

Table 1: Characteristics of respondents $(n=404)$

\begin{tabular}{lll}
\hline Characteristics & Frequency & Percentage \\
\hline Age & & \\
17-19 years old & 202 & 50 \\
$20-22$ years old & 149 & 36.9 \\
$23-25$ years old & 7 & 2.7 \\
25 years old & 46 & 11.4 \\
Educational level & & \\
$\quad$ Diploma students & 254 & 62.9 \\
Undergraduate students & 131 & 32.4 \\
Graduate students & 19 & 4.7 \\
Semester taken & & \\
1 & 74 & 18.3 \\
2 & 70 & 17.3 \\
3 & 134 & 33.2 \\
4 & 54 & 13.4 \\
5 & 40 & 9.9 \\
6 & 28 & 6.9 \\
7 & 2 & 0.5 \\
8 & 2 & 0.5 \\
Information Technology Skills & & 2.7 \\
Low & 11 & 82.2 \\
Intermediate & 332 & 15.1 \\
High & 61 & 75.5 \\
The experience of participating in online learning before the pandemic & 24.5 \\
Never & 305 & \\
Once & 99 &
\end{tabular}

Figure 1 shows the types of platforms that are often used by students in online learning and dominantly use Zoom (61.6\%), there are also students who use other platforms such as WhatsApp groups, Google Classroom, and others.

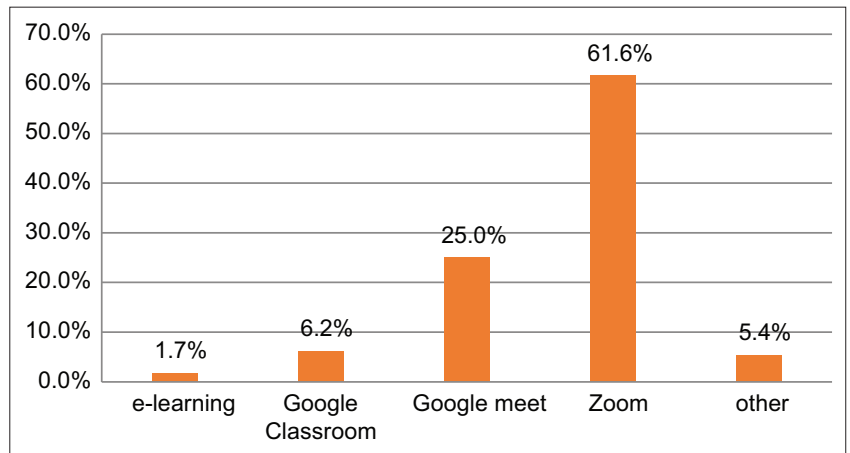

Figure 1: Platforms used in online learning

Figure 2 shows the percentage of students' perceptions about the advantages of online learning and it was found that the majority said thanks to online learning, students can still stay at home $(22.2 \%)$ and easily access online sources of material $(19.9 \%)$ and can record/obtain recordings of each lesson $(18.6 \%)$.

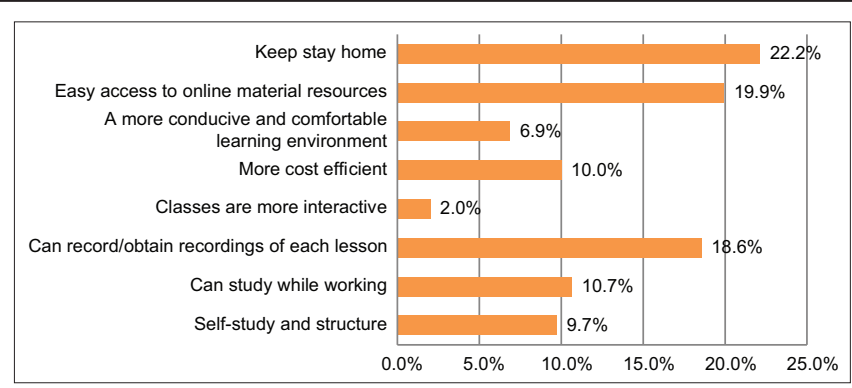

Figure 2: The advantages of online learning

Figure 3 shows the percentage of students' perceptions of the weaknesses of online learning and it is found that the majority revealed that when online learning, technical problems often occur (24.6\%), interaction with lecturers is very minimal (18.4\%) as well as interaction between students is very minimal $(17.5 \%)$.

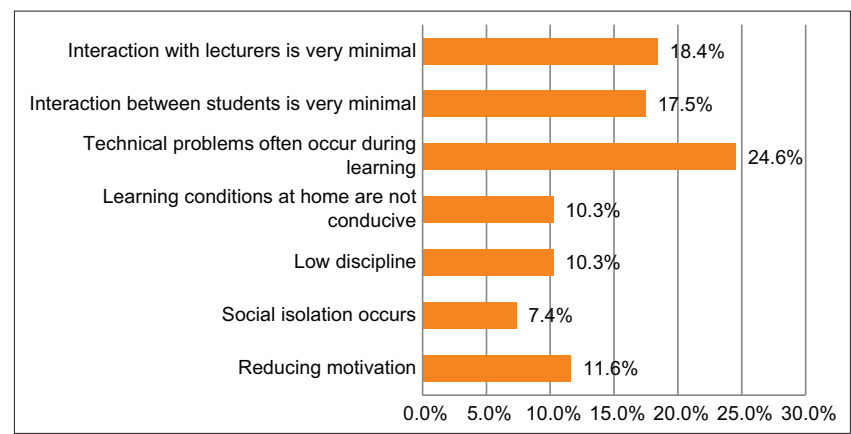

Figure 3: Weaknesses of online learning

Table 2 shows students' perceptions of online learning, assessed using a Likert scale from 1 to 5 , the higher the average, and the better the student's perception. Of the 12 statement items, there are two items with the highest average answer (Score 4), namely, students perceive that online learning can improve students' skills in using media/platforms and online learning can improve students' social competence.

Table 2: Average student perceptions of online learning ( $n=404$ )

\begin{tabular}{|c|c|c|c|}
\hline No & Student perception & mean & SD \\
\hline 1 & Student understanding of online lectures with lecturers & 3.10 & 0.699 \\
\hline 2 & $\begin{array}{l}\text { There are wider and more diverse interactions/networks } \\
\text { during online learning }\end{array}$ & 3.49 & 0.876 \\
\hline 3 & $\begin{array}{l}\text { There is an increase in the motivation of students and } \\
\text { lecturers when learning online }\end{array}$ & 3.27 & 0.935 \\
\hline 4 & $\begin{array}{l}\text { Lecturer material updates are more comprehensive } \\
\text { during online learning }\end{array}$ & 3.49 & 0.850 \\
\hline 5 & $\begin{array}{l}\text { Collaboration and interaction between students are } \\
\text { better when learning online }\end{array}$ & 3.04 & 0.938 \\
\hline 6 & $\begin{array}{l}\text { The online learning process increases learning } \\
\text { activities (asking; answering; taking notes; and } \\
\text { discussing) }\end{array}$ & 3.29 & 0.941 \\
\hline 7 & $\begin{array}{l}\text { Online learning increases student interest in being able } \\
\text { to access other online materials }\end{array}$ & 3.56 & 0.890 \\
\hline 8 & $\begin{array}{l}\text { Online learning increases students' independence and } \\
\text { skills in using media }\end{array}$ & 3.88 & 0.827 \\
\hline 9 & $\begin{array}{l}\text { Online learning can enhance the learning experience } \\
\text { with various platforms/media }\end{array}$ & 4.01 & 0.747 \\
\hline 10 & $\begin{array}{l}\text { Online learning can improve students' media/platform } \\
\text { skills }\end{array}$ & 4.01 & 0.715 \\
\hline 11 & $\begin{array}{l}\text { Online learning can improve social competence in } \\
\text { students }\end{array}$ & 3.23 & 0.912 \\
\hline 12 & Student's impression of online learning & 3.27 & 0.972 \\
\hline
\end{tabular}


The perception score is then categorized with a cutoff point using the median value of the data (median $=41$ ) which means that if the total score of the respondent's answers is $>41$ then the perception is declared positive, while if the total score of the respondent's answer is 41 then the perception is declared negative. It was found that most respondents had a negative perception (52.2\%) about online learning (Table 3).

Table 3: Categorization of student perceptions regarding online learning

\begin{tabular}{lll}
\hline Perception & Frequency & Percentage \\
\hline Negative & 211 & 52.2 \\
Positive & 193 & 37.8 \\
Total & 404 & 100 \\
\hline
\end{tabular}

Further analysis was conducted to find out what factors influence student perceptions and the results are presented in the following table:

Table 4: Factors that influence student perceptions

\begin{tabular}{|c|c|c|c|c|}
\hline \multirow[t]{2}{*}{ Characteristics } & \multicolumn{2}{|l|}{ Perception } & \multirow[t]{2}{*}{ Total $\mathrm{f}(\%)$} & \multirow[t]{2}{*}{ p-value ${ }^{*}$} \\
\hline & Negative f (\%) & Positive f (\%) & & \\
\hline \multicolumn{4}{|l|}{ Age } & \multirow{5}{*}{0.045} \\
\hline $17-19$ years old & $110(54.4)$ & $92(45.5)$ & $202(100)$ & \\
\hline $20-22$ years old & $82(55)$ & $67(45)$ & $67(100)$ & \\
\hline $23-25$ years old & $4(57.1)$ & $3(42.9)$ & $7(100)$ & \\
\hline$>25$ years old & $15(32.6)$ & $31(67.4)$ & $46(100)$ & \\
\hline \multicolumn{4}{|l|}{ Educational level } & \multirow[t]{4}{*}{0.063} \\
\hline Diploma students & $144(56.7)$ & $110(43.3)$ & $254(100)$ & \\
\hline Undergraduate students & $59(45)$ & $72(55)$ & $131(100)$ & \\
\hline Postgraduate students & $8(42.1)$ & $11(57.9)$ & $19(100)$ & \\
\hline \multicolumn{4}{|c|}{ Information and Technology Skills (IT) } & \multirow[t]{4}{*}{0.040} \\
\hline Low & $7(63.6)$ & $4(36.4)$ & $11(100)$ & \\
\hline Median & $181(54.5)$ & $151(45.5)$ & $332(100)$ & \\
\hline High & $23(37.7)$ & $38(62.3)$ & $61(100)$ & \\
\hline \multicolumn{4}{|c|}{ The experience of participating in online learning before the pandemic } & \multirow[t]{3}{*}{0.962} \\
\hline Never & $160(52.5)$ & $145(45.7)$ & $305(100)$ & \\
\hline Once & $51(51.5)$ & $48(48.5)$ & $99(100)$ & \\
\hline
\end{tabular}

In tabel 4 , the results of statistical tests showed that age and IT skills had a significant effect on students' perceptions of online learning $(p<0.05)$. This is supported by the distribution of data which show that the 17-25-year age group tends to have a negative perception, while the $>25$-year age group has a positive perception. It can be said that the more mature the age, the more positive the student's perception of online learning. Based on IT skills, it shows that students who have low skills tend to have negative perceptions while students who have high skills dominantly have positive perceptions. It can be said that the more skilled students are in IT, the more positive their perceptions about online learning are.

\section{Discussion}

The research that we did was to find out the weaknesses and strengths of online learning during the COVID-19 pandemic, especially nursing students at several universities in Indonesia. In addition, I also want to know the most frequently used learning platforms and nursing students' perceptions of online learning and the factors that influence it. From our research, the majority of respondents are aged 17-19 years with the most education level being Diploma students. The most of the respondents are students who are currently studying in the third semester, and most of them already have knowledge and skills about middle-level information technology. Regarding the online learning experience, the most of the students had never participated before the COVID-19 pandemic.

Just like other studies, it was reported that the most of the students who were taking online learning during the COVID-19 pandemic had never been familiar with online learning. Although the students have never been formally introduced to E-Learning at university, some of them have knowledge of several platforms used such as Alison and Google Classroom; this may be the students study alone or take private lessons [25], [26], [27].

In our research, Zoom is a platform that is often used by students in online learning, followed by Google Meet and Google Classroom. Research conducted in Ghana on 467 students, the most frequently used online learning platforms during the COVID-19 pandemic were WhatsApp (50.5\%), Google Meet (18.2\%), and Zoom meeting (17.6\%), while others using YouTube and Facebook [27]. Another study also reported that the platform that is often used to conduct online learning is WhatsApp [28], [29]. In addition, there are also those who use a combination platform WhatsApp with Zoom meetings, and WhatsApp with Google Classroom [29]. Reasons for using WhatsApp are that every lecturer and student has the application on their smartphone. With WhatsApp, you can have discussions to discuss lectures through WhatsApp groups (WAG). This application allows all members to share files of various types. Including college assignments can also be collected into WAG. Other platforms that are often used are Email, Google Classroom, and Zoom meetings [28].

A report supports our research, the platform that is widely used in the online learning process in Italy, Japan, the US, and China is Zoom meeting [30]. The most significant advantage of using Zoom meetings is that there is a discussion through video which can then be recorded and stored in hard drives [31]. Through video platforms enable a sense of connection between lecturers and students for reciprocal discussions and sharing of other information in real time [32].

Students' perceptions of the advantages of learning through Zoom, most of them revealed that learning activities can be followed from home and easily access learning materials even though they live far from the city and can record or obtain recordings every time there is a learning process. Besides that, it also feels comfortable to be able to study at home [33].

The data that we obtained show that the weakness of online learning that is felt by students is that it is often disrupted due to network problems and other technical problems, the lack of interaction between students and lecturers and interaction between students. Another study showed that the weakness of online learning 
is that some teachers face technical difficulties using online platforms and creating e-content to deliver material to students, thus disrupting the process of transferring knowledge to students. An unstable internet connection is a problem that often interferes with the quality of the learning process. With some of these obstacles, students show a less serious attitude in carrying out the tasks given to students. Teachers and students alike find it difficult to carry out the online learning process well [29], [34]. For medical students, online learning causes interactions with patients to be greatly reduced, thereby reducing the quality of learning [33].

Students' perceptions of online learning are that they can improve skills in using technology, information, and communication in the form of learning platforms/media and online learning can improve social competence. However, based on the scores, we made in this study, we found that the most of the respondents had negative perceptions about online learning. In contrast to the Sri Lanka study of 171 students, it showed that most were satisfied with online learning during the COVID-19 pandemic [34]. A Polish study of 804 medical students assessed that most of them were happy with online learning; however, they stated that online learning was less effective for training skills than face-to-face learning [33].

Student perceptions of online learning are influenced by several factors, including the age of the respondents, and skills in using information technology. In the 17-25-year age group, they tend to have negative perceptions. Meanwhile, the age group above 25 years has a positive perception, which means that most agree and accept online learning well. Hence, it can be said that the more mature the respondent is; the perception of online learning is positive. For students who have high skills in using ICT show positive perceptions, while those with low skills tend to have negative perceptions. Of course, those who are familiar with information technology will find it easier to use the platform used for online learning and will not experience many obstacles, so the perception is positive. Meanwhile, students who are less skilled will definitely have difficulty using the learning platform resulting in negative perceptions. To determine the acceptance of online learning, we do not use a special method but only by knowing the perceptions of students. If students have negative perceptions, it means that online learning acceptance is also low.

A cross-sectional and web-based study was conducted on 340 medical students at King Abdulaziz University, 2020. Using Google forms for data collection, there are three constructs, namely, tutor quality, perceived usefulness, and facilitating conditions. as a standard measure of E-Learning acceptance measure. The conclusion is that it is sufficient for medical students to accept E-Learning during the COVID-19 pandemic. Moreover, it is recommended to increase training for students and tutors, improve e-course design, increase interaction, motivation, and increase blended learning [35].
Not many studies discuss the factors that influence the perception and acceptance of online learning models.

\section{Conclusion}

Online education and learning processes are the right choices at a time when the COVID-19 pandemic sweeps across the world, which requires physical and social distancing to be implemented. There are advantages to online learning, but there are also many obstacles faced by lecturers and students to implement it. The most of the students have never experienced online learning and many do not understand the use of ICT in this new model of learning.

The change in the learning process from faceto-face models in the classroom to distance learning or online is a challenge for students in particular. From our research, the most frequently used platform is Zoom because it has the advantage that students and teachers can interact through video and can record it during lectures which can then be stored on a computer or smartphone. Regarding the perception of nursing students toward online learning during the COVID-19 pandemic, most of them have negative perceptions, which means they do not like the learning process of the model and prefer face-to-face learning.

\section{Acknowledgment}

The authors thank to the Health Research Ethics Committee of the KRMTWongsonegoro Hospital, Semarang City, who has given research permission and the respondents who took part in the research.

\section{Ethical Consideration}

The authors have entirely observed ethical issues (Including plagiarism, informed consent, misconduct, data fabrication and/or falsification, double publication and/or submission, redundancy, etc.).

\section{References}

1. Byrnes YM, CivantosAM, GoBC, McWilliams TL, Rajasekaran K. Effect of the COVID-19 pandemic on medical student career perceptions: 
A national survey study. Med Educ Online. 2020;25(1):1798088. https://doi.org/10.1080/10872981.2020.1798088

PMid:32706306

2. Cucinotta D, Vanelli M. WHO declares COVID-19 a pandemic. Acta Biomed. 2020;91(1):157-60. https://doi.org/10.23750/abm. v91i1.9397

PMid:32191675

3. Pramana C, Herawati S, Santi N, Rosreri, Maryani LP, Dachliana OR. The first case of COVID-19 in Semarang, Indonesia: A case report. Int J Pharm Res. 2020;12(2):1875-8.

4. Supinganto A, Pramana C, Sirait LI, Fitri ML, Kumalasari, Hadi $\mathrm{Ml}$, et al. The use of masks, as an effective method in preventing the transmission of the COVID-19, during pandemic and the new Normal Era: A review. Int J Pharm Res. 2020;13(2):558-64.

5. Susilawaty A, Noviyanto F, Afrianty I, Syahputra A, Kurniasari L, Handoko L, et al. Attitude, risk perception and public acceptance against Coronavirus disease 2019 vaccination in Indonesia. Open Access Maced J Med Sci. 2021;9(E):717-21.

6. Kemendikbud. Surat Edaran Nomor 4 Tahun 2020 tentang Pelaksanaan Kebijakan Pendidikan Dalam Masa Darurat Penyebaran Coronavirus Diseaase (COVID-19); 2020. Available from: https://www.pusdiklat.kemdikbud.go.id/surat-edaranmendikbud-no-4-tahun-2020-tentang-pelaksanaan-kebijakanpendidikan-dalam-masa-darurat-penyebaran-corona-virusdisease-covid-1-9 [Last accessed on 2020 Mar 24].

7. Hazaymeh WA. EFL students' perceptions of online distance learning for enhancing English language learning during covid19 Pandemic. Int J Instr. 2021;14(3):501-18.

8. Zamari ZM, Adnan AH, Idris SL, Yusof J. Students' perception of using online language learning materials. Proc Soc Behav Sci. 2012;67:611-20. https://doi.org/10.1016/j.sbspro.2012.11.367

9. McKnight K, O'Malley K, Ruzic R, Horsley M, Franey JJ, Bassett K. Teaching in a digital age: How educators use technology to improve student learning. J Res Technol Educ. 2016;48(3):194-211.

10. Pramana C, Susanti QV, Yoteni F, Rusdiana YJ, Purwoko RY, Hasnawati NR, et al. Virtual learning during the COVID-19 pandemic, a disruptive technology in higher education in Indonesia. Int J Pharm Res. 2020;12(2):3209-16.

11. Almahasees Z, Mohsen K, Amin MO. Faculty's and students perceptions of online learning during COVID-19. Front Educ. 2021;6:1-10.

12. Limbong T, Simarmata J. Determining effective subjects online learning (study and examination) with multi-attribute utility theory (MAUT) method. J RESTI. 2020;4(2):370-6.

13. Hikmat $\mathrm{H}$, Hermawan $\mathrm{E}$, Aldim A, Irwandi I. Efektivitas Pembalajaran Daring Selama Masa Pandemi COVID-19: Sebuah Survey Online. Bandung: Digit Libr UIN SUnan Gung Djati; 2020. p. 1-7.

14. Al-Salman S, Haider AS. Jordanian university students' views on emergency online learning during covid-19. Online Learn J. 2021;25(1):286-302.

15. Mcbrien JL, Cheng R, Jones P. View of virtual spaces: Employing a synchronous online classroom to facilitate student engagement in online learning, The international review of research in open and distributed learning. Int Rev Res Open Distrib Learn. 2009;10(3):1-17.

16. Cojocariu VM, Lazar I, Nedeff V, Lazar G. SWOT anlysis of E-learning educational services from the perspective of their beneficiaries. Proc Soc Behav Sci. 2014;116:1999-2003. https:// doi.org/10.1016/j.sbspro.2014.01.510

17. Ehlers JM. Quality in European E-learning: An introduction. In: Handbook on Quality and Standardisation in E-Learning. Berlin, Heidelberg: Springer; 2006. p. 1-13. https://doi. org/10.1007\%2F3-540-32788-6_1

18. Hodges C, Moore S, Lockee B, Trust T, Bond A. The Difference between Emergency Remote Teaching and Online Learning,
EDUCAUSE Review; 2020. p. 1-12. Available from: https:// www.er.educause.edu/articles/2020/3/the-difference-betweenemergency-remote-teaching-and-. [Last accessed on 2021 Aug 25].

19. Al-Azawei A, Parslow P, Lundqvist K. Investigating the effect of learning styles in a blended E-learning system: An extension of the technology acceptance model (TAM). Australas J Educ Technol. 2017;33(2):1-23.

20. Englund C, Olofsson AD, Price L. Teaching with technology in higher education: Understanding conceptual change and development in practice. High Educ Res Dev. 2017;36(1):7387. https://doi.org/10.1080/07294360.2016.1171300

21. Diki D. International collaboration of distance learning universities for online learning in indonesia. Lux. 2013;2(1):1-8.

22. Boltuc, P. Global learning through collaboration. Formamente, Rivista Internationale di Ricerca sul Futuro Digitale GUIDE Association, Rome, Italy, 2008;3(1/2):145-154.

23. Kustandi C, Fadhillah DN, Situmorang R, Prawiradilaga DS, Hartati S. VR use in online learning for higher education in Indonesia. Int J Interact Mob Technol. 2020;14(1):31-47.

24. Pegu UK. Information and communication technology in higher education in India: Challenges and opportunities. Int $\mathrm{J}$ Inf Comput Technol. 2014;4(5):513-8.

25. Rusmiati AR, Reza R, Achmad S, Syaodih E, Nurtanto M, Sultan $A$, et al. The perceptions of primary school teachers of online learning during the COVID-19 pandemic period: A case study in Indonesia. J Ethn Cult Stud. 2020;7(2):90-109.

26. Giatman M, Siswati S, Basri IY. Online learning quality control in the pandemic COVID-19 Era in Indonesia. J Nonform Educ. 2020;6(2):168-75.

27. Agormedah EK, Adu Henaku E, Ayite DM, Ansah EA. Online learning in higher education during COVID-19 pandemic: A case of Ghana. J Educ Technol Online Learn. 2020;3(3):183-210.

28. Gunawan G, Suranti NM, Fathoroni F. Variations of models and learning platforms for prospective teachers during the COVID19 Pandemic Period. Indones J Teach Educ. 2020;1(2):75-94.

29. Hassan MM, Mirza MW. A critical review by teachers on the online teaching-learning during the COVID-19. Int J Educ Manag Eng. 2020;10(6):17-27.

30. Mola R. Microsoft, Google, and Zoom are Trying to Keep up with Demand for their Now free Work-From-Home Software; 2020. Available from: $\mathrm{https}: / / w w w . v o x . c o m / r e c o d e / 2020 / 3 / 11 / 21173449 /$ microsoft-google-zoom-slack-increased-demand-free-work-fromhome-software [Last accessed on 2020 Mar 11].

31. de Oliveira Dias DM, Lopes DR, Teles AC. Will virtual replace classroom teaching? Lessons from virtual classes via zoom in the times of COVID-19. J Adv Educ Philos. 2020;4(5):208-13.

32. Vandenberg S, Magnuson M. A comparison of student and faculty attitudes on the use of Zoom, a video conferencing platform: A mixed-methods study. Nurse Educ Pract. 2021;54:103138. https://doi.org/10.1016/j.nepr.2021.103138

33. Baczek M, Zaganczyk-Baczek M, Szpringer M, Jaroszynski A, Wozakowska-Kapłon B. Students' perception of online learning during the COVID-19 pandemic A survey study of Polish medical students. Medicine (Baltimore). 2021;100(7):e24821. https:// doi.org/10.1097/MD.0000000000024821 PMid:33607848

34. Howshigan S, Nadesan T. Students' perceptions of online learning and teaching during COVID-19 pandemic: An empirical study in Selected University in Sri Lanka. Asian J Econ Bus Account. 2021;21(8):50-7.

35. Ibrahim NK, Al Raddadi R, Al Darmasi M, Al Ghamdi A, Gaddoury M, Al Bar HM, et al. Medical students' acceptance and perceptions of e-learning during the COVID-19 closure time in King Abdulaziz University, Jeddah. J Infect Public Health. 2021;14(1):17-23. https://doi.org/10.1016/j.jiph.2020.11.007 PMid:33341480 